\title{
Strategi Bersaing Perusahaan Taksi Dalam Menghadapi Perubahan Lingkungan
}

\author{
Ahmad Saifi Athoillah ${ }^{1)}$, Muhammad Firdaus ${ }^{2)}$, Bunasor Sanim ${ }^{3)}$, \\ ${ }^{1}$ Sekolah Bisnis, Institut Pertanian Bogor \\ email: ahmadsaifiathoillah@outlook.com \\ ${ }^{2.3}$ Fakultas Ekonomi dan Manajemen, Institut Pertanian Bogor
}

\begin{abstract}
This study aimed to analyze the satisfaction of taxi passengers, analyze the internal and external factors in PT A and formulate the competitive strategy with conventional taxi competitor and online taxi companies. The scope og this research is specifically focused on the competitive staretgy at strategic business unit level. This study is uses quantitative and quantitative descriptive approach. Data analysis techniques used are porter five score model, IFE, EFE, IE and QSPM. The results of this study on the analysis of IFE, PT A shows that the highest strength is on a strong, strategic distribution network of taxi in big cities. Meanwhile, the highest threat is standardization of tariff, number of taxi, and minimum identify of online taxi. Furthermore, IE matrix analysis shows that PT A is in quadrant I (grow and build strategy). The decision making stage with QSPM matrix has the order of strategic prority as follows: forward integration, backward integration, horizontal integration, product development, market penetration, and market development.
\end{abstract}

Keywords: EFE, IFE, IPA, QSPM, competitive strategy

\begin{abstract}
Abstrak
Tujuan penelitian ini untuk menganalisis tingkat kepuasan penumpang taksi, menganalisis faktor-faktor internal dan eksternal PT A, dan merumuskan strategi bersaing PT A dengan perusahaan taksi konvensional pesaing dan taksi online. Ruang lingkup penelitian ini berfokus pada strategi bersaing level strategi bisnis unit. Penelitian ini menggunakan pendekatan deskriptif kuantitatif dan kualitatif. Teknik analisis data yang digunakan adalah Porter Five Force Score Model, IFE, EFE, IE, dan QSPM. Hasil penelitian ini menunjukkan bahwa analisis IFE, pada faktor kekuatan PT A adalah jaringan distribusi taksi yang kuat dan strategis di kota-kota besar. Faktor kelemahannya adalah posisi keuangan perusahaan yang tidak kuat. Pada analisis EFE, faktor peluangnya adalah tingkat mobilitas dan kebutuhan transportasi yang tinggi. Sedangkan faktor ancamannya adalah standarisasi tarif, jumlah armada, dan identitas taksi online yang minim. Pada matriks IE, PT A berada pada kuadran I (strategi pertumbuhan dan membangun). Pengambilan keputusan dengan QSPM, urutan strategi prioritas yaitu: integrasi ke depan, integrasi ke belakang, integrasi horizontal, pengembangan produk; penetrasi pasar, pengembangan pasar.
\end{abstract}

Kata Kunci: EFE, IFE, IPA, QSPM, strategi bersaing 


\section{A. PENDAhULUAN}

Dalam satu dekade ini secara umum industri taksi mengalami perkembangan yang cukup signifikan yaitu sejak masuknya taksi berbasis aplikasi atau online pada tahun 2014. Dengan inovasi yang diberikan layanan taksi, masyarakat cukup menggunakan smartphone dapat memesan taksi yang disediakan oleh perusahaan taksi.

Hadirnya taksi online ini menciptakan siklus lingkungan ekonomi digital yang mengarah pada mobile transportation, hal ini diharapkan mampu memberdayakan ekonomi masyarakat khususnya UKM secara luas melalui digitalisasi berbasis aplikasi (Mulyati dan Utami 2019).

Hadirnya tren ini membuat perusahaan-perusahaan besar taksi konvensional yang lebih dahulu berjaya dituntut untuk menerapkan strategi bersaing yang tepat dan sustainable.

Salah satu perusahaan taksi konvensional yang mengalami dampak besar akibat masuknya taksi online adalah PT A. PT A merupakan perusahaan operator taksi konvensional swasta terbesar di Indonesia. Perusahaan yang berlokasi di Jakarta ini dari sisi market share sebesar 30\% pasar taksi nasional. PT A mengalami fluktuasi pendapatan dan operasional sejak datangnya taksi online. Terdapat 3 masalah yang dihadapi perusahaan.

Pertama adalah menurunya kinerja keuangan akibat menurunnya setoran pengemudi pada tahu 20152017, sebagaimana terlihat pada tabel 1 .

Tabel 1. Laporan Keuangan PT A Tahun 2015-2017 Dalam Miliar (Kecuali Dinyatakan Lain)

\begin{tabular}{|l|r|r|r|}
\hline Keterangan & 2015 & 2016 & 2017 \\
\hline Revenue & 970,1 & 618,2 & 231,6 \\
\hline Gross profit & 341 & 74,1 & $-123,7$ \\
\hline $\begin{array}{l}\text { Income } \\
\text { before tax }\end{array}$ & 50,7 & $-223,4$ & $-102,4$ \\
\hline Net income & 32,2 & $-184,7$ & $-133,1$ \\
\hline EBITDA & 514,4 & 246,2 & $-52,4$ \\
\hline Total asset & $2.883,8$ & $2.557,2$ & $2.392,1$ \\
\hline $\begin{array}{l}\text { Total } \\
\text { Liabilities }\end{array}$ & $1.962,8$ & $1.820,5$ & $1.866,3$ \\
\hline
\end{tabular}

Sumber: Diolah dari annual report PT A tahun 2012 - 2016 dan laporan keuangan 2017

Tabel 1 menunjukkan nilai revenue PT A cenderung mengalami penurunan. Hal yang menarik diperhatikan adalah revenue pada tahun 2016, tingkat revenue mulai mengalami penurunan sebesar $36.27 \%$ atau menjadi Rp 618.2 miliar dibandingkan tahun 2015 yaitu Rp 970.1 miliar. Penurunan ini berlanjut sampai tahun 2017 bahwa tingkat revenue turun tajam sebesar $62.54 \%$ menjadi Rp 231.6 miliar dibandingkan tahun 2016 sebesar Rp 618.2 miliar.

Kedua adalah produktifitas pengemudi dan operasional taksi. Hadirnya taksi online memberikan 
dampak pada tingkat produktifitas setoran yang rendah. Hal ini berakibat pada penurunan $40 \%$ setoran per harinya. Keadaan ini membuat PT A mengalami penurunan jumlah taksi yaitu tahun 2014-2017 sebesar 1.350 tahun menjadi 9.700 taksi.

Ketiga adalah kompetisi tarif yang tinggi dan menurunnya market share. Tingkat kompetisi tarif yang tinggi membuat PT A kurang bersaing dalam hal tarif taksi, sehingga pengemudi tidak mencapai standar setoran yang diberikan kepada perusahaan. Tarif taksi PT A dinilai lebih tinggi dari taksi online yaitu rata-rata $30 \%$ lebih murah tarif per km. Tarif taksi online yang murah ini mengakibatkan beralihnya penumpang taksi konvensional ke taksi online. Melihat lebih jauh ketiga permasalahan PT A, maka sangat penting PT A untuk strategi bersaing.

Tujuan penelitian ini adalah 1) menganalisis faktor-faktor lingkungan internal dan eksternal yang mempengaruhi PT A; 2) merumuskan strategi bersaing PT A untuk mencapai keunggulan bersaing dalam perusahaan taksi. Ruang lingkup penelitian terdiri atas subjek dan objek. Subjek penelitian ini adalah strategi bersaing perusahaan taksi jenis reguler. Sedangkan objek penelitian adalah PT A. Batasan objek adalah lingkup strategi bersaing pada level unit bisnis. Dalam penelitian ini PT A bersaing dengan 1 perusahaan taksi konvensional yaitu PT B, dan 3 perusahaan taksi online yaitu PT C, PT D, dan PT E.

\section{B. TINJAUAN PUSTAKA}

\section{Taksi konvensional dan online}

Taksi adalah transportasi darat non pribadi yang umumnya adalah jenis sedan dan merujut pada angkutan lain selain mobil yang mengangkut penumpang berkapasitas kecil dengan standar 2-4 penumpang (KBBI 2008). Apabila dikaitkan dengan fenomena taksi online terdapat perbedaan dengan taksi konvensional, seperti Tabel 2.

Tabel 2. Perbedaan Antara Taksi

Konvensional dan Berbasis Online

\begin{tabular}{|l|l|l|}
\hline \multicolumn{1}{|c|}{ Indikator } & Konvensional & $\begin{array}{l}\text { Berbasis } \\
\text { Online }\end{array}$ \\
\hline Tarif & $\begin{array}{l}\text { Tergantung } \\
\text { argometer }\end{array}$ & $\begin{array}{l}\text { Tergantung } \\
\text { aplikasi }\end{array}$ \\
\hline Pembayaran & $\begin{array}{l}\text { Tunai, kartu } \\
\text { kredit/debet }\end{array}$ & $\begin{array}{l}\text { Tunai, e- } \\
\text { money }\end{array}$ \\
\hline $\begin{array}{l}\text { Kepemilikan } \\
\text { kendaraan }\end{array}$ & $\begin{array}{l}\text { Milik } \\
\text { perusahaan }\end{array}$ & Milik pribadi \\
\hline KIR & $\begin{array}{l}\text { Uji KIR 6 } \\
\text { bulan sekali }\end{array}$ & $\begin{array}{l}\text { Tidak perlu } \\
\text { uji KIR }\end{array}$ \\
\hline $\begin{array}{l}\text { Plat dan } \\
\text { pajak }\end{array}$ & $\begin{array}{l}\text { Berplat } \\
\text { kuning dan } \\
\text { membayar } \\
\text { pajak }\end{array}$ & $\begin{array}{l}\text { Berplat } \\
\text { hitam, tidak } \\
\text { perlu } \\
\text { membayar } \\
\text { pajak } \\
\text { kendaraan. }\end{array}$ \\
\hline
\end{tabular}

Sumber: Indonesia Investment (2017), data diolah 


\section{Strategi Bersaing}

Strategi bersaing adalah mengembangkan rencana mengenai bagaimana bisnis akan bersaing, apa yang seharusnya menjadi tujuan dan kebijakan apa yang diperlukan untuk mencapai tujuan tersebut (Porter 2001). Menurut Porter bahwa peta persaingan pasar melibatkan 5 kekuatan persaingan atau disebut five force porter yaitu:
a. Ancaman dari pendatang baru
b. Hambatan masuk
c. Kekuatan tawar menawar
d. Kekuatan pembeli
e. Ancaman dari produk substitusi

\section{Strategi-strategi}

persaingan perusahaan taksi

Zhao dan Xing (2012), melakukan penelitian dengan menggunakan metode IPA. Hasil penelitian bahwa kuadran IPA pada taksi online dengan tingkat kinerja yang tinggi berada pada kuadran II. Artinya penumpang lebih tertarik memesan taksi dengan smartphone daripada pemesanan taksi konvensional dan segala keunggulan taksi online baik dari sisi reliability, responsiveness, assurance, empathy, dan tangibles.

Chaudhary dan Joshi (2016) menggunakan model five porter force dan SWOT. Hasil penelitian menunjukkan terdapat 2 strategi. Strategi pertama adalah menciptakan layanan yang berbeda dan angkutan lain. Kedua adalah pajak kendaraan pribadi yang tidak dialokasikan untuk pembangunan infrastruktur public. Kesamaan penilian ini dengan penulis adalah terletak pada objek yang dikaji.

Subagja (2016) menggunakan metode five force porter, SWOT, BCG, dan QSPM. Tujuan penelitian ini untuk menganalisis strategi bisnis dan pemasaran PT Blue Bird Tbk. Hasil penelitian strategi alternatif yang diterapkan perusahaan yaitu 1) penambahan armada taksi; 2) meningkatkan cakupan pada lokasi baru terutama pada tingkat kota madya; 3) meingkatkan kualitas layanan dan efisiensi operasi; 4) meningkatkan devisi limousine di beberapa kota; 5) meningkatkan profitabilitas perusahaan.

Hasian (2014) melakukan penelitian dengan metode play to win analysis, five force porter, dan VRIO. Tujuannya untuk menganalisis stratgei PT Express Transindo Utama Tbk dengan sesama taksi konvensional. Hasil penelitian menunjukkan bahwa strategi yang paling tepat diterapkan perusahaan adalah strategi best cost 


\section{CAPITAL \\ JURNAL EKONOMI DAN MANAJEMEN \\ P-ISSN: 2598-9022/ E-ISSN: 2598-9618 \\ Available at: http://e-journal.unipma.ac.id/index.php/capital}

provider. Strategi ini berfokus pada cost

leadership dan strategi diferensiasi.

\section{Faktor-faktor keberhasilan bisnis \\ taksi}

Zhang et al. (2016) melakukan penelitian dengan variabel dependen yang digunakan adalah menganalisis permintaan untuk taksi. Sedangkan variabel independen yang digunakan ada tiga faktor, yaitu 1) pesanan taksi melalui online; 2) tingkat konsentrasi pengemudi; 3) tujuan sosial yang baik pada perusahaan taksi. Hasil penelitian menunjukkan bahwa ketiga faktor tersebut berdampak pada permintaan layanan taksi online.
Perbedaan dengan penelitian yang dilakukan penulis adalah pada subjek, objek, metode dan cakupan bahasan. Pada subjek penelitian menggunakan strategi bersaing perusahaan taksi jenis reguler. Objek penelitian adalah PT A. Sedangkan metode analisis yang digunakan adalah Porter Five Force Model, Internal Factor Evaluation (IFE), External Factor Evaluation (EFE), InternalExternal (IE), Quantitative Strategic Planning Matrix (QSPM). Cakupan penelitian adalah strategi bersaing pada level unit bisnis. Alur konsep pemikiran penelitian ini terlihat pada Gambar 2.

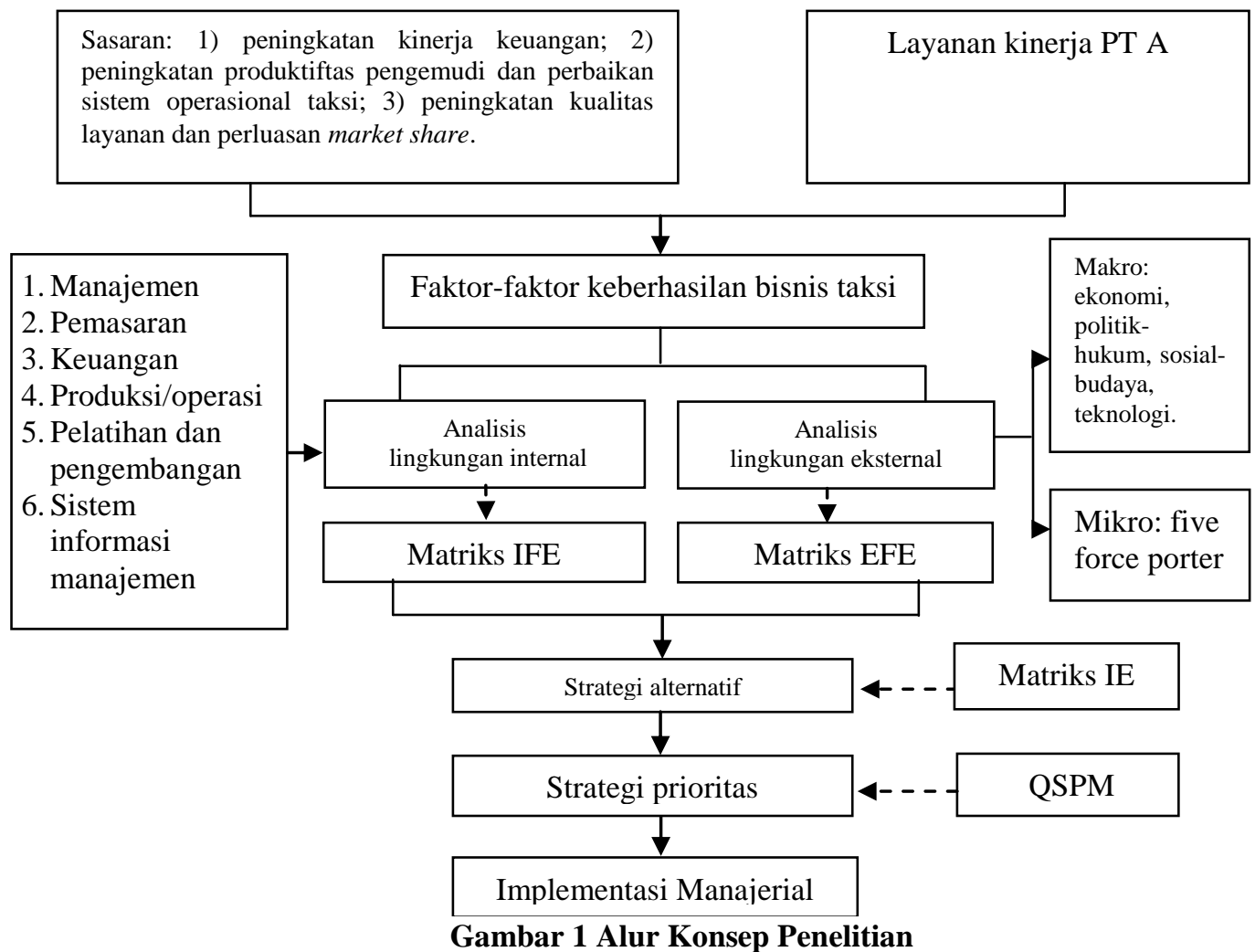


Penelitian ini termasuk dalam penelitian studi kasus (case study) dengan pendekatan deskriptif kuantitatif yaitu pendekatan yang lebih menekankan pada aspek pengukuran sistematis, terencana dan terstruktur secara objektif terhadap suatu organisasi, lembaga dan gejala tertentu yang menjadi fenomena sosial di masyarakat (Sugiyono 2012).

Jenis dan sumber data dalam penelitian ini menggunakan data primer dan data sekunder. Data primer didapat dari survei kuesioner kepada responden ahli. Responden ahli terdiri ada dua pihak, yaitu pihak internal dan ekternal.

Pihak internal kepada petinggi manajemen PT A. Pihak eksternal yaitu Dinas Perhubungan dan Transportasi DKI Jakarta yang terdiri atas dua responden ahli. Data sekunder berasal dari literature pustaka yaitu jurnal, buku, dan data lain yang kredibel.

Jumlah sampel wawancara berjumlah 7 responden ahli yaitu 5 petinggi manajemen PT A yaitu: People Development Manager, Industrial and Reklation Manager, Head Human Capital, General Affair Manager, dan Staf Rekrutmen. Sedangkan 2 responden ahli dari Dishub DKI Jakarta, yaitu Kepala Bidang Angkutan Jalan
Orang Dalam Trayek Dishub DKI, dan Staf Bidang Angkutan Jalan Orang Dalam Trayek.

Teknik pengumpulan data penelitian ini dilakukan dengan survei kuesioner, observasi, wawancara dan studi pustaka.

Teknik analisis data menggunakan beberapa metode yaitu :

\section{Five force porter model}

Metode untuk menganalisis daya tarik industri dalam jangka waktu panjang. Penelitian ini menggunakan skor penilaian 1-4 yaitu 1) rendah; 2) sedang; 3) tinggi; 4) sangat tinggi.

\section{Internal Factor Evaluation (IFE)}

Matriks IFE adalah metode yang digunakan dalam manajemen strategis untuk mengevaluasi kekuatan dan kelemahan (Zulkarnain et al. 2018).

3. External Factor Evaluation (EFE)

Matriks EFE adalah metode untuk menilai respon perusahaan terhadap kondisi eksternalnya (Zulkarnain et al. 2018).

\section{Internal-External (IE)}

Matriks IE didasarkan pada analisis faktor-faktor lingkungan internal dan eksternal yang digabungkan menjadi satu model sugestif pada Gambar 2. 


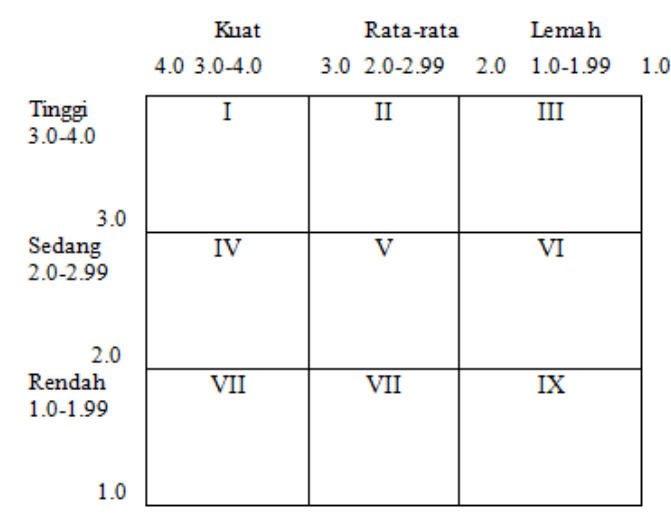

Gambar 2. Matriks Internal-External (IE)

Pada Gambar 3 terlihat bahwa apabila divisualisasikan, perusahaan harus memegang dan mempertahankan posisinya. Terdapat 9 sel strategi dan secara ringkas dikelompokann menjadi 3 strategi utama (Kuncoro 2005), yaitu:

a. Growth strategy merupakan strategi pertumbuhan perusahaan itu sendiri (sel 1, 2 dan 5) ataua upaya diversivikasi produk (sel 7 dan 8).

b. Stability strategy adalah strategi yang diterapkan tanpa mengubah arah strategi yang diterapkan.

c. Retrenchment strategy (sel 3, 6, dan 9) merupakan strategi memperkecil atau mengurangi usaha yang dilakukan perusahaan.

5. Quantitative strategic planning

Metode analisis untuk mengevaluasi strategi alternatif secara objektif berdasarkan faktor-faktor keberhasilan internal dan eksternal (David 2011).
Teknik pengolahan data dalam penelitian ini menggunakan beberapa tahapan yaitu sebagai berikut :

a. Observasi lingkungan internal perusahaan dilakukan dengan melihat keadaan internal PT A dan Dishub DKI Jakarta.

a. Wawancara berdasarkan kuesioner kepada responden ahli. Pada tahapan ini untuk menentukan bobot dan rating pada matriks IFE dan EFE. Pada tahapan ini untuk menjawab tujuan penelitian pertama yaitu menganalisis faktorfaktor internal dan eksternal yang mempengaruhi PT A.

b. Analisis matriks Internal-External (IE), outputnya menghasilkan strategi alternatif yang direkomendasikan perusahaan.

c. Analisis QSPM yang outputnya menghasilkan urutan strategi prioritas. Hasil output dari analisis ini adalah untuk menjawab tujuan penelitian ke kedua yaitu merumuskan strategi bersaing PT A.

\section{HASIL DAN PEMBAHASAN}

\section{Analisis Lingkungan Internal}

Perusahaan 


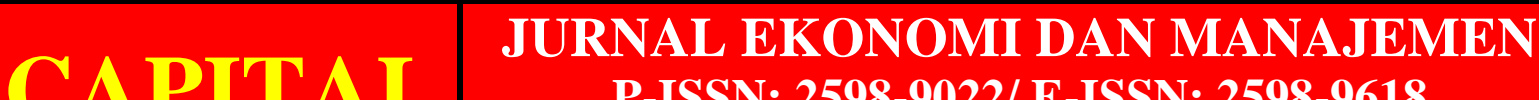 \\ P-ISSN: 2598-9022/ E-ISSN: 2598-9618 \\ Available at: http://e-journal.unipma.ac.id/index.php/capital}

Evaluasi Matriks Internal Factor

\section{Evaluation (IFE)}

Analisis matriks IFE merupakan hasil dari identifikasi faktor internal berupa kekuatan (strengths) dan kelemahan (weakness) yang dimiliki PT A dari analisis lingkungan internal sebagaimana terlihat pada Tabel 3. Pada Tabel 3 terlihat hasil perhitungan menggunakan matriks IFE diperoleh total skor yang dimiliki PT A sebesar 3.3733 .
Dengan skor bobot total di atas 2.5 mengindikasikan bahwa posisi internal perusahaan cukup mampu mengatasi kelemahan yang ada dengan kekuatan yang dimilikinya. Lebih lanjut, hasil dari matriks IFE menunjukkan bahwa faktor kekuatan yang mempunyai pengaruh besar adalah jaringan distribusi taksi yang kuat dan strategis di kota-kota besar (skor 0.2187). Sedangkan faktor kelemahan utama PT A adalah posisi keuangan yang tidak kuat (skor 0.1991).

Tabel 3. Hasil Analisis Matriks IFE Pada PT A

\begin{tabular}{|l|c|c|c|}
\hline \multicolumn{1}{|c|}{ Faktor Internal } & Bobot & Rating & Skor \\
\hline \multicolumn{1}{|c|}{ Kekuatan } & & & \\
\hline Jumlah armada dan poll taksi yang banyak. & 0.0476 & 3.2 & 0.1524 \\
\hline Jaringan distribusi taksi yang kuat di kota besar. & 0.0547 & 4.0 & 0.2187 \\
\hline Kualitas layanan yang handal. & 0.0488 & 3.6 & 0.1755 \\
\hline Tarif batas bawah taksi PT A. & 0.0502 & 4.0 & 0.2008 \\
\hline Loyalitas pengemudi dan penumpang yang tinggi. & 0.0478 & 3.2 & 0.1530 \\
\hline Jumlah pengemudi yang banyak. & 0.0449 & 3.0 & 0.1348 \\
\hline $\begin{array}{l}\text { Maintenance produksi dan operasi (pengadaan taksi, } \\
\text { peralatan\&perlengkapan suku cadang). }\end{array}$ & 0.0557 & 2.6 & 0.1449 \\
\hline Efisiensi biaya operasional perusahaan. & 0.0562 & 3.8 & 0.2134 \\
\hline Lokasi kantor dan poll yang strategis. & 0.0557 & 3.8 & 0.2116 \\
\hline Perusahaan memiliki diversitas (VATB) dan taksi premium. & 0.0603 & 3.6 & 0.2172 \\
\hline Kemampuan kerjasama/mitra pemerintah/non pemerintah. & 0.0468 & 3.6 & 0.1683 \\
\hline $\begin{array}{l}\text { Sistem kemitraan pengemudi dengan perusahaan berjalan baik } \\
\text { dan saling menguntungkan. }\end{array}$ & 0.0482 & 2.6 & 0.1254 \\
\hline Tunjangan/insentif karyawan yang baik. & & & \\
\hline \multicolumn{1}{|c|}{ Kelemahan } & & & \\
\hline Revitalisasi armada taksi membutuhkan biaya yang tinggi. & 0.0531 & 2.8 & 0.1486 \\
\hline Posisi keuangan yang tidak kuat. & 0.0498 & 4.0 & 0.1991 \\
\hline Revitalisasi infrastruktur teknologi dengan biaya tinggi. & 0.0459 & 4.0 & 0.1837 \\
\hline Minimnya penelitian, pengembangan dan inovasi. & 0.0478 & 2.0 & 0.0955 \\
\hline Produktivitas setoran pengemudi yang turun. & 0.0451 & 3.6 & 0.1623 \\
\hline Minimnya kemampuan SDM dalam hal teknologi. & 0.0473 & 3.0 & 0.1420 \\
\hline Pemasaran dan Promo tarif cenderung pasif. & 0.0407 & 3.8 & 0.1547 \\
\hline & 1 & 3.3733 \\
\hline
\end{tabular}




\section{capras a \\ P-ISSN: 2598-9022/ E-ISSN: 2598-9618 \\ Available at: http://e-journal.unipma.ac.id/index.php/capital}

\section{Analisis Lingkungan Eksternal}

\section{Perusahaan}

\section{Lingkungan Makro-Mikro}

Analisis porter five force model dalam penelitian ini terdiri atas lima komponen yaitu ancaman pendatang baru, daya tawar pemasok, daya tawar pembeli, ancaman produk pengganti, rivalitas/hambatan masuk pada Tabel 4.
Pada Tabel 4 terlihat bahwa pada daya tarik ancaman pendatang baru, yang dihadapi oleh PT A dalam persaingan taksi online adalah kebutuhan modal dan peraturan pemerintah, dengan skor masingmasing sebesar 4.00. Analisis Tabel 4 bahwa untuk memenangkan persaingan industri taksi PT A harus memperhatikan kedua kekuatan tersebut

Tabel 4. Rekapitulasi Hasil Kuesioner Model Analisis Five Force Porter

\begin{tabular}{|c|c|c|c|}
\hline \multicolumn{2}{|c|}{$\begin{array}{l}\text { Lingkup industri } \\
\end{array}$} & Skor & Keterangan \\
\hline \multicolumn{4}{|c|}{ Ancaman pendatang baru } \\
\hline 1 & Skala ekonomi & 2.50 & Tinggi \\
\hline 2 & Diferensiasi penghalang masuk & 2.75 & Tinggi \\
\hline 3 & Kebutuhan modal & 4.00 & Sangat tinggi \\
\hline 4 & Akses saluran distribusi & 3.75 & Sangat tinggi \\
\hline 5 & Kualitas produk dari penghalang & 3.00 & Sangat tinggi \\
\hline 6 & Peraturan pemerintah & 4.00 & Sangat tinggi \\
\hline 7 & Tindakan penolakan yang diperkirakan & 2.25 & Sedang \\
\hline 8 & Harga penghalang masuk & 3.75 & Sangat tinggi \\
\hline 9 & Teknologi hambatan masuk & 3.75 & Sangat tinggi \\
\hline 10 & Pengalaman sebagai hambatan masuk & 2.25 & Sedang \\
\hline \multicolumn{4}{|c|}{ Daya tawar pemasok } \\
\hline 1 & Kelompok pemasok & 3.50 & Sangat tinggi \\
\hline 2 & Produk substitusi & 2.75 & Tinggi \\
\hline 3 & Pelanggan penting & 4.00 & Sangat tinggi \\
\hline 4 & Pemerintah & 4.00 & Sangat tinggi \\
\hline \multicolumn{4}{|c|}{ Daya tawar pembeli } \\
\hline 1 & Kelompok pelanggan/Penumpang & 3.75 & Sangat tinggi \\
\hline 2 & Diferensiasi produk & 4.00 & Sangat tinggi \\
\hline 3 & Ancaman integrasi pelanggan & 3.50 & Sangat tinggi \\
\hline 4 & Kualitas produk & 3.25 & Tinggi \\
\hline 5 & Harga/tarif taksi & 4.00 & Sangat tinggi \\
\hline \multicolumn{4}{|c|}{ Ancaman produk pengganti } \\
\hline 1 & Transportasi umum & 4.00 & Sangat tinggi \\
\hline 2 & Kendaraan pribadi & 3.75 & Sangat tinggi \\
\hline 3 & Ojek & 3.75 & Sangat tinggi \\
\hline \multicolumn{4}{|c|}{ Tingkat rivalitas persaingan } \\
\hline 1 & Jumlah kompetitor & 3.00 & Tinggi \\
\hline 2 & Tingkat pertumbuhan industri & 3.00 & Tinggi \\
\hline 3 & Biaya tetap yang besar & 4.00 & Sangat tinggi \\
\hline
\end{tabular}




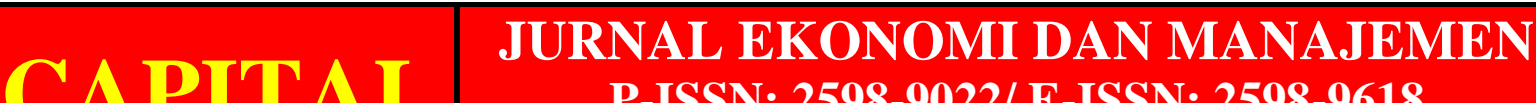 \\ P-ISSN: 2598-9022/ E-ISSN: 2598-9618 \\ Available at: http://e-journal.unipma.ac.id/index.php/capital}

Kekuatan daya tawa pemasok, daya tarik tertinggi adalah pelanggan dan pemerintah, dengan skor masingmasing 4.00. Pada daya pembeli, kekuatan tertinggi yaitu diferensiasi produk dan harga dengan masingmasing sebesar 4.00. Ancaman produk pengganti dalam industri taksi adalah transportasi umum (skor 4.00). Adapun rivalitas/hambatan masuk adalah biaya taksi yang tetap (skor 4.00).

\section{Analisis Matriks External Factor Evaluation (EFE)}

Analisis pada matriks EFE merupakan - hasil dari identifikasi faktor eksternal berupa peluang dan ancaman yang berpengaruh pada PT A, kemudian dilakukan pembobotan seperti yang terlihat pada Tabel 5. Tabel 5 diperoleh nilai total skor sebesar 3.3645. Dengan skor bobot di atas 2.5 mengindikasikan bahwa perusahaan mampu merespon dengan baik faktor eksternal dengan memanfaatkan peluang yang ada untuk mengatasi ancaman. Peluang utama yang dimiliki perusahaan adalah tingkat mobilitas dan kebutuhan transportasi yang tinggi dengan skor sebesar 0.2554.

Tabel 5. Hasil Analisis Matriks EFE PT A

\begin{tabular}{|c|c|c|c|}
\hline Faktor Eksternal & Bobot & Rating & Skor \\
\hline \multicolumn{4}{|l|}{ Peluang } \\
\hline $\begin{array}{l}\text { Regulasi pemerintah dalam menetapkan aturan taksi } \\
\text { konvensional dan taksi online. }\end{array}$ & 0.0565 & 3.1 & 0.1750 \\
\hline Tingkat mobilitas dan kebutuhan transportasi yang tinggi. & 0.0639 & 4.0 & 0.2554 \\
\hline Daya tawar pemasok taksi yang kuat. & 0.0540 & 2.3 & 0.1243 \\
\hline Pertumbuhan penduduk yang meningkat & 0.0498 & 3.6 & 0.1791 \\
\hline Tingkat pertumbuhan ekonomi Indonesia yang baik. & 0.0439 & 3.3 & 0.1450 \\
\hline Bersaing di pangsa pasar menengah. & 0.0399 & 3.3 & 0.1316 \\
\hline Strategi fokus di domestik market. & 0.0396 & 3.1 & 0.1229 \\
\hline Perkembangan teknologi informasi yang pesat. & 0.0484 & 3.3 & 0.1596 \\
\hline Daya beli masyarakat yang tinggi. & 0.0546 & 4.0 & 0.2184 \\
\hline Meningkatnya jumlah perkantoran dan tempat hiburan. & 0.0586 & 3.9 & 0.2287 \\
\hline Diferensiasi taksi yang relatif rendah. & 0.0595 & 2.4 & 0.1427 \\
\hline Dukungan pendanaan investor dan stakeholder. & 0.0525 & 3.7 & 0.1944 \\
\hline \multicolumn{4}{|l|}{ Ancaman } \\
\hline Masuknya taksi online. & 0.0509 & 3.4 & 0.1730 \\
\hline Isu-isu tarif taksi murah di masyarakat. & 0.0543 & 3.3 & 0.1791 \\
\hline Ancaman produk substitusi taksi. & 0.0490 & 3.1 & 0.1520 \\
\hline $\begin{array}{l}\text { Standarisasi tarif, jumlah armada dan identitas kendaraan } \\
\text { taksi online yang minim }\end{array}$ & 0.0534 & 4.0 & 0.2135 \\
\hline Persaingan dalam industri taksi yang tinggi & 0.0431 & 3.4 & 0.1464 \\
\hline Izin kepemilikan kendaraan yang mudah oleh pemerintah. & 0.0416 & 3.9 & 0.1623 \\
\hline Kemajuan teknologi perusahaan pesaing. & 0.0442 & 3.9 & 0.1723 \\
\hline Inflasi dan kenaikan harga input. & 0.0423 & 2.1 & 0.0887 \\
\hline Total & 1 & & 3.3645 \\
\hline
\end{tabular}




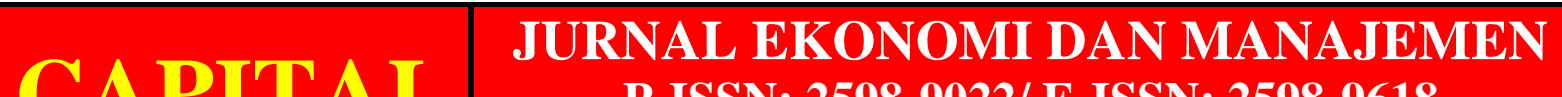 \\ P-ISSN: 2598-9022/ E-ISSN: 2598-9618 \\ Available at: http://e-journal.unipma.ac.id/index.php/capital}

Ancaman utama PT A adalah

standarisasi tarif, jumlah armada, dan identitas kendaraan taksi online yang minim dengan skor sebesar 0.2135.

\section{Analisis Matriks Internal-External}

Analisis matriks Internal-

External (IE) dilakukan untuk mempertajam analisis pada matriks IFE dan EFE. Berdasarkan pemetaan total skor pada matriks IFE yaitu sebesar 3.3733, dapat disimpulkan bahwa PT A memiliki tingkat faktor internal yang tinggi.

Dari kondisi ini, artinya PT A mampu mengelola kekuatan dan kelemahan yang terdapat dalam industri taksi. Sedangkan total skor pada matriks EFE yaitu sebesar 3.3645.
Artinya perusahaan dapat mengelola peluang, serta mampu memitigasi resiko atas ancaman dalam industri taksi. Secara lengkap hasil pembobotan dapat dapat disimpulkan bahwa PT A memiliki tingkat tinggi dalam merespon atau memanggapi lingkungan eksternalnya. matriks faktor internal dan eksternal yang selanjutnya dimasukkan dalam matriks IE seperti pada Gambar 4. Pada Gambar 4 bahwa posisi PT A berada pada sel I yaitu growth and build strategy. Strategi ini dalam pengaplikasiannya berada pada level unit bisnis yaitu lebih menekankan pada bagaimana perusahaan menggerakkan organisasinya ke depan dalam unit bisnis taksi regular seperti pada Tabel 6 .

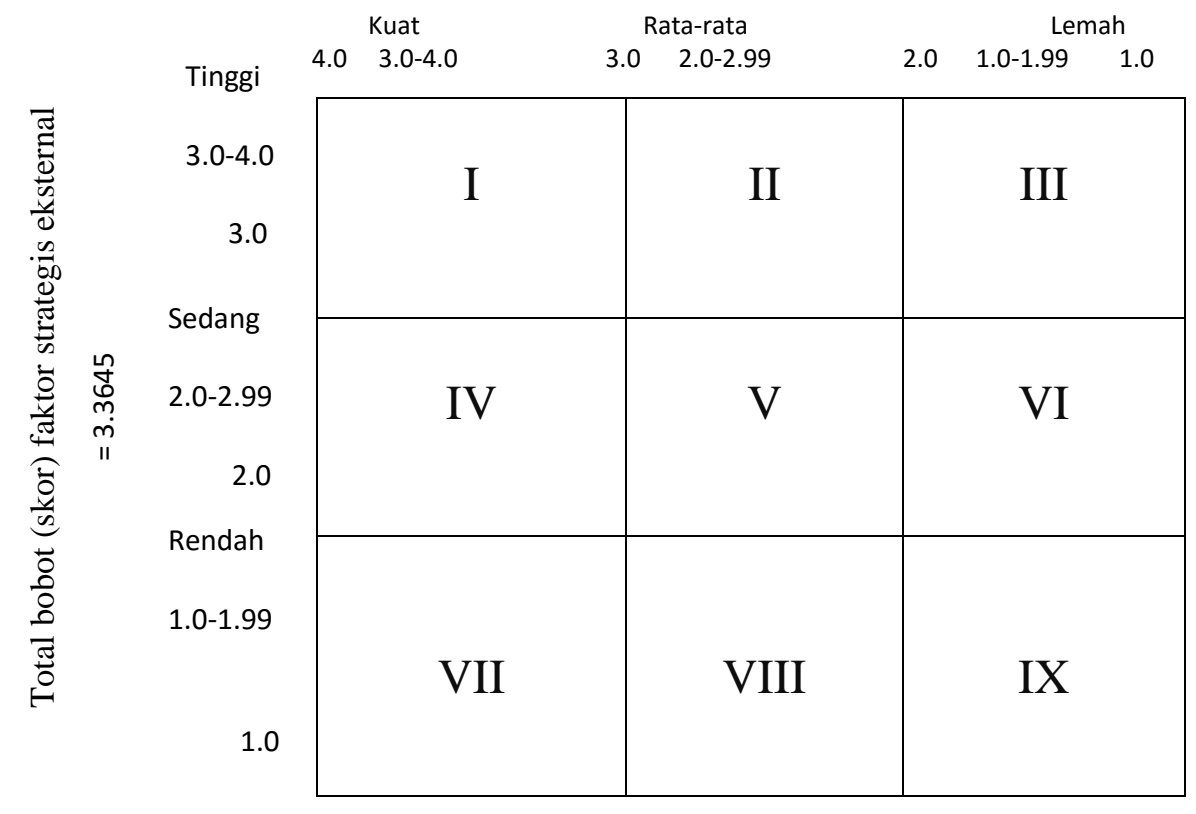

Gambar 3 Total Skor Matriks IE PT A 
Tabel 6. Strategi-Strategi Alternatif PT A

\begin{tabular}{|c|c|c|}
\hline No & Strategi alternatif & Program strategi yang direkomendasikan \\
\hline \multirow[t]{2}{*}{1} & $\begin{array}{l}\text { Strategi integrasi } \\
\text { vertikal ke depan }\end{array}$ & $\begin{array}{l}\text { a. Mengoptimalkan pendapatan melalui diversitas produk Value Added } \\
\text { Transportation Business (VATB) dan taksi premium yang belum } \\
\text { optimal. } \\
\text { b. Efisiensi cash flow dari sisi maintenance produksi dan operasi. }\end{array}$ \\
\hline & & $\begin{array}{l}\text { c. Merevitalisasi dan peremajaan armada taksi. } \\
\text { d. Menambah kerjasama dengan instansi pemerintah/non pemerintah dan } \\
\text { perusahaan pada bidang lain. }\end{array}$ \\
\hline \multirow[t]{2}{*}{2} & $\begin{array}{l}\text { Strategi integrasi } \\
\text { ke belakang }\end{array}$ & $\begin{array}{l}\text { a. Efisiensi karyawan pada fungsi-fungsi kerja yang tidak lagi optimal dan } \\
\text { produktif. }\end{array}$ \\
\hline & & $\begin{array}{l}\text { b. Menempatkan lokasi kantor administrasi yang strategis dan } \\
\text { menempatkan lokasi poll taksi yang strategis pula dari pusat ekonomi } \\
\text { masyarakat. } \\
\text { c. Menambah jaringan taksi di kota (diluar wilayah operasional). } \\
\text { d. Menambah sumber pendanaan alternatif selain pinjaman dari bank untuk } \\
\text { memperkuat keuangan. }\end{array}$ \\
\hline 3 & $\begin{array}{l}\text { gi integrasi } \\
\text { ontal }\end{array}$ & $\begin{array}{l}\text { a. Meningkatkan kerjasama dengan pemasok kendaraan (ATPM) dan } \\
\text { pemasok komponen lain. } \\
\text { b. Menambah kerjasama dengan perusahaan taksi online lain. } \\
\text { c. Meningkatkan kesejahteraan pengemudi melalui peninjuan kembali } \\
\text { sistem kemitraan serta kesejahteraan hari tua. } \\
\text { d. Kerjasama perusahaan Teknologi dalam upaya pengembangan aplikasi } \\
\text { taksi milik PT A. }\end{array}$ \\
\hline 4 & $\begin{array}{l}\text { Strategi } \\
\text { pengembangan } \\
\text { produk }\end{array}$ & $\begin{array}{l}\text { a. Mengembangkan produk taksi dengan segmen kaum muda. } \\
\text { b. Melakukan riset terhadap segmen pasar kaum muda dan inovasi-inovasi } \\
\text { dalam pemasarannya. } \\
\text { c. Mendifensiasikan taksi kaum muda dengan konsep: Strategy, Targeting, } \\
\text { Positioning (STP) yang tepat. } \\
\text { d. Meningkatkan kualitas layanan dan skill pengemudi. } \\
\text { e. Membuka office channeling di beberapa lokasi strategis perkantoran dan } \\
\text { tempat-tempat hiburan. } \\
\text { Diversitas produk taksi pada segmen kaum muda. }\end{array}$ \\
\hline 5 & $\begin{array}{l}\text { Strategi penetrasi } \\
\text { pasar }\end{array}$ & $\begin{array}{l}\text { a. Menambah wilayah jaringan operasional taksi yaitu area Jabodetabek } \\
\text { pada segmen taksi kaum muda. } \\
\text { b. Menambah jumlah pengemudi taksi. } \\
\text { c. Melakukan promosi atas penetapan diferensiasi produk taksi reguler } \\
\text { kaum muda di area Jabodetabek. } \\
\text { d. Mempertahankan tarif batas bawah pada taksi reguler (low cost tariff) } \\
\text { pada sasaran konsumen menengah. }\end{array}$ \\
\hline 6 & $\begin{array}{l}\text { Strategi } \\
\text { pengembangan } \\
\text { pasar }\end{array}$ & $\begin{array}{l}\text { a. Berfokus pada pasar domestik } \\
\text { b. Melakukan promosi secara intensif dengan memberi diskon, promo, } \\
\text { voucer kepada masyarakat/instansi pemerintahan di luar Jabodetabek } \\
\text { pada segmen taksi kaum muda. } \\
\text { c. Merekrut karyawan dibidang Teknologi dan Informasi (IT), Marketing, } \\
\text { dan Keuangan. }\end{array}$ \\
\hline
\end{tabular}


Pengambilan Keputusan Strategi

\section{Prioritas PT A}

Berikut ini urutan strategi prioritas dalam pengambilan keputusan dengan metode QSPM :

1. Strategi integrasi vertikal ke depan dengan total TAS sebesar 6.3715.

2. Strategi integrasi vertikal ke belakang total TAS sebesar 6.3201.

3. Strategi integrasi horizontal dengan total TAS sebesar 6.1892.

4. Strategi pengembangan produk dengan total TAS sebesar 5.9429.

5. Strategi penetrasi pasar dengan total TAS sebesar 5.9203.

6. Strategi pengembangan pasar dengan total TAS sebesar 5.7897.

\section{Implikasi Manajerial}

Berikut adalah implikasi manajerial yang diaplikasikan PT A:

1. Strategi integrasi kedepan

a. Mengoptimalkan pendapatan melalui diversitas lini unit bisnis lain seperti sewa bus, limunsin dan taksi premium.

b. Efisiensi cash flow dari sisi maintenance dari sisi operasi (pengadaan taksi, perlengkapan suku cadang, serta bahan bakar). Langkah strategis adalah mengganti
BBM dengan bahan bakar gas atau biogas (eco taxi).

c. Merevitalisasi dan peremajaan kembali armada taksi.

d. Menambah kerjasama dengan instansi pemerintah dan perusahaan e-commerce maupun fintech seperti traveloka, tokopedia, booking.com, tiket.com dll.

2. Strategi integrasi ke belakang

a. Efisensi jumlah karyawan pada fungsi kerja yang tidak optimal.

b. Memperkuat posisi keuangan perusahaan dengan mencari sumber pendanaan selain pinjaman dari bank, misalnya menjual aset-aset yang tidak produktif, penerbitan surat hutang obligasi, right issue.

3 Strategi integrasi horizontal

a. Meningkatkan kerjasama dengan pemasok kendaraan (ATPM), seperti Toyota, Honda, dll.

b. Menambah kerjasama dengan perusahaan taksi online lain.

$4 \quad$ Strategi pengembangan produk

a. Mendiferensiasikan taksi kaum muda dengan konsep Segmentation, Targeting, Positioning (STP). Sisi segmentation berdasarkan data demografi usia yaitu rentang 21-30 tahun di Jabodetabek. Pada targeting adalah masyarakat kaum 
muda (usia 21-30 tahun). Pada

positioning yaitu memposisikan dirinya sebagai taksi kaum muda.

b. Membuka office channeling dan menambah shelter taksi di beberapa lokasi strategis perkantoran, perbelanjaan, dan hiburan, seperti di Indomaret, mall, dan lainnya.

c. Penambahan diversitas produk taksi kaum muda.

5. Strategi penetrasi pasar

a. Menambah wilayah operasional taksi diluar Jabodetabek pada segmen taksi kaum muda.

b. Menambah jumlah pengemudi.

c. Mempromosikan secara intensif pada produk taksi kepada anak muda di area Jabodetabek.

d. Mempertahankan tarif batas bawah dengan fokus pada konsumen ekonomi menengah.

6. Strategi pengembangan pasar

a. Berfokus pada pasar domestik.

b. Merekrut karyawan dibidang teknologi dan informasi, keuangan, dan marketing.

\section{E. SIMPULAN}

Berdasarkan hasil evaluasi lingkungan internal didapatkan faktor tertinggi dari sisi kekuatan adalah jaringan distribusi taksi yang kuat dan strategis di kota-kota besar. Faktor kelemahannya adalah posisi keuangan perusahaan yang tidak kuat. Pada analisis evaluasi lingungan eksternal faktor peluang tertinggi adalah tingkat mobilitas dan kebutuhan transportasi yang tinggi. Faktor ancamannya adalah standarisasi tarif, jumlah armada, dan identitas taksi online yang minim.

Hasil analisis perumusan strategi bersaing dengan matriks IE menunjukkan bahwa perusahaan berada pada sel ke I (grow and build).

Hasil pengambilan keputusan menggunakan metode QSPM dengan hasil urutan strategi prioritas adalah: 1) strategi integrasi ke depan; 2) integrasi ke belakang; 3) integrasi horizontal; 4) pengembangan produk; 5) penetrasi pasar; 6) strategi pengembangan pasar.

\section{DAFTAR PUSTAKA}

Asosiasi Penyelenggara Jasa Internet Indonesia. 2016. Statistik Pengguna Internet Indonesia. Jakarta: APJII.

Chaudhary, M. L., Joshi., C. Y. (2016). Strategy analysis of urban public transport industry: a case of Ahmedabad, Gujarat in India. Journal NMIMS Management in India, 19(9), 81-101.

David, F. R. (2011). Strategic Management: Manajemen Strategi 
Konsep. Edisi 12. Jakarta: Salemba Empat.

Express Group. (2016). Annual report PT Express Transindo Utama Tbk Tahun 2016. [internet]. [diunduh 2018 januari 25]. Tersedia pada: http://www.expressgroup.co.id

Hasian, A. (2014). Formulasi strategi bersaing PT Express Transindo Utama Tbk (Express Group) dalam memenangkan persaingan bisnis taksi di Jakarta [tesis]. Yogyakarta: Universitas Gajah Mada.

He. F., \& Shen, Z. J. (2015). Modeling taxi services with smartphone based e-hailing applications. Journal of Transport Policy, 58(3), 93-106.

Indonesia Investment. 2017. Blue Bird Group. [internet]. [diunduh 2017 Februari 9]. Tersedia pada: http://www.indonesiainvestments.com/id/bisnis/profilperusahaan/blue-birdgroup/item 415 ?

Kuncoro, M. (2015). Strategi: Bagaimana Meraih Keunggulan Kompetitif: Jakarta: Penerbit Erlangga.

Mulyati, T., \& Utami, S. B. Penguatan usaha kecil menengah Melalui program tanggungjawab social perusahaan (Studi PT INKA Persero). Jurnal Capital, 2(2), 116137.

Pusat Bahasa Departemen Pendidikan Nasional. (2008). Kamus Besar Bahasa Indonesia. Jakarta: Pusat Bahasa Departemen Pendidikan Nasional.
Porter, M. E. (2001). Strategi Bersaing: Teknik Menganalisis Industri dan Pesaing. Jakarta: Erlangga.

Subagja, I. K. (2016). Pelaksanaan strategi bisnis dan pemasaran PT Blue Bird Tbk. Manajemen Bisnis Krisnadwipayana, 4(3), 1-18.

Sugiyono. (2012). Metode Penelitian Kuantitatif Kualitatif dan $R \& D$. Bandung: Alfabeta.

Warpani, S. (1990). Merencanakan Sistem Perangkutan. Bandung: Institut Teknologi Bandung.

Wit, B. D., \& Mayer, R. (2003). Strategy: Process, Content, Context. $3^{\text {th }}$ Ed. London: Thompson Learning.

Zhang, J., Li, J., \& Lu, S. (2016). Factors affecting the demand for the taxi evidence from Zhejiang, China. Review of Integrative Business and Economic Research, 5(4), 379-394.

Zhao, L., \& Xing, J. (2012). Taxi operation and management system based on distributed only taxi stations soving strategy. Applied Mechanics And Materials, 25(255), 1833-1836.

Zulkarnain, A., Whyuningtias, D., \& Putranto, T. S. (2018). Analysis of IFE, EFE, and QSPM matrix on business development strategy, Earth And Environmental Science, 126(62), 1-7. 


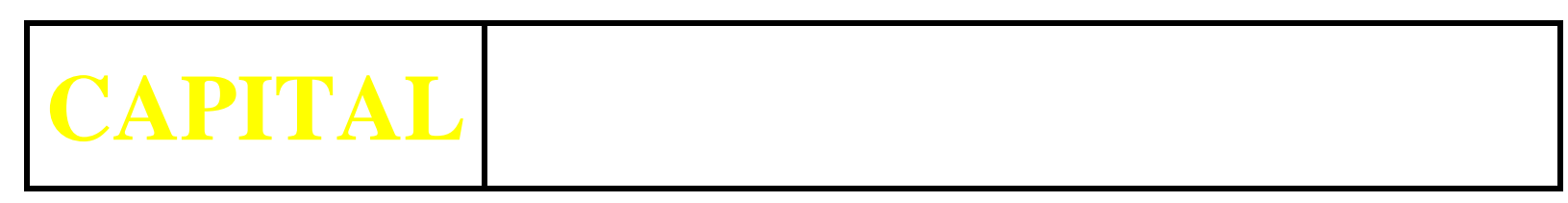

